\title{
Desempenho de 15 variedades de soja plantadas em terra firme, na Fazenda Araçá, Manaus, em 1976
}

\author{
Fazal Rahman ( ${ }^{\star}$ )
}

\begin{abstract}
Resumo
Treze variedades de soja anteriormente incluidas num experimento na várzea e duas novas introduçōes, Pickett 71 e Calland, foram plantadas em 30/06/76 na terra firme (Fazenda Araçá $\mathrm{km} 4$ da BR-319, Manaus-Porto Velho), onde a floresta foi derrubada há 8 anos. A produção de sementes foi baixa neste experimento principalmente devido ao atraso no plantio. No presente trabalho são discutidas brevemente as possiveis causas da baixa produtividade e são feitas recomendações para uma melhor avaliação do plantio de variedades de soja em terra firme. Hampton 266A fo: a variedade que mais produziu neste experimento, com $563 \mathrm{~kg}$ por hectare, enquanto que Júpiter, com uma produção de $4.588 \mathrm{~kg}$ por hectare na várzea de Caldeirão, produziu apenas $400 \mathrm{~kg}$ por hectare na terra firme. Esta mesma variedado Júpiter produziu $2.100 \mathrm{~kg} / \mathrm{ha}$ em um canteiro de multiplicação de sementes próximo da área do experimento, plantado com 42 dias de antecedência. A época de plantio de soja em terra firme carece ser ajustada de modo que o tempo de maturidade das plantas coincida com a estação seca.
\end{abstract}

\section{INTRODUÇÃo}

Quinze vari€dades de soja dos E.U.A. toram testadas em uma área de terra firme da Amazônia. As variedades foram enviadas pelo Programa Internacional de Soja (INTSOY). As sementes foram plantadas com atraso de 4 meses da época de plantio.

O objetivo deste experimento foi o de testar o desempenho de vários cultivares de soja na terra firme onde a floresta foi removida há um tempo relativamente longo (no caso, há cerca de 8 anos). Entretanto, nåo foi possível fazer uma avaliação justa devido ao atraso no plantio das sementes, o qual expôs as plantas a uma falta de água.

\section{MATERIAIS E MÉTODOS}

As variedades foram plantadas em canteiros de 4 linhas, de $5 \mathrm{~m}$ de comprimento cada; a distância entre linhas foi de $60 \mathrm{~cm}$ e entre as plantas foi de $5 \mathrm{~cm}$. O modelo experimental foi o de blocos totalmente casualizados, nos quais cada uma das 15 variedades foi replicada 4 vezes. As variedades incluídas no experimento estão indicadas na Tabela 1.

Em 14/04/76 foi aplicado calcário na proporção de 2 toneladas por hectare, enquanto que $\mathrm{P}_{2} \mathrm{O}_{5}$ e $\mathrm{KCl}$ foram adicionados na proporção de 35 e $66 \mathrm{~kg}$ por hectare, respectivamente, dois dias antes do plantio das sementes em 30/06/76. O inoculante Rhizobium japonicum foi aplicado no solo na base de $5 \mathrm{~g}$ por linha de $5 \mathrm{~m}$. Plantio, colheita e debulha foram realizados manualmente neste experimento. Os inseticidas Azodrin e Malathion foram aplicados de tempos em tempos a fim de controlar alguns besouros não identificados no campo. Os dados coletados se referem à produção, número de dias requeridos para florescimento e maturidade, altura da planta, acamamento, número de plantas colhidas das duas fileiras centrais, número de vagens por planta (média de 10 plantas), peso de 100 sementes, qualidade das sementes e índice de doenças. Somente as duas fileiras centrais foram utilizadas para coleta de dados.

Os dados foram analisados em computador e com metodologia adequada para análise de variância. O teste da diferença mínima significativa (LSD) foi empregado para comparações de médias.

\section{RESUltados E DISCUSSÃo}

Na Tabela 1 estão contidos os dados sobre produção, número de dias requeridos para florescimento e maturidade, altura da planta, acamamento, número de plantas colhidas, número de vagens por planta, peso de 100 sementes qualidade das sementes e índice de doenças. A Tabela 2 contém os resultados da análise de variância para cada variável.

(*) - Instituto Nacional de Pesquisas da Amazônia; Manaus. 
TABELA 1 - Dados sobre a produção, número de dias para florescimento e maturidade (a partir da germinação), altura da planta, acamamento, número de plantas colhidas, número de vagens por planta (média de 10 plantas), peso de 100 sementes, qualidade das sementes e índice de doença de 15 variedades de soja plantadas em terra firme na Fazenda Araçá, em 30 de junho de 1976.

\begin{tabular}{|c|c|c|c|c|c|c|c|c|c|c|c|}
\hline \multirow{2}{*}{ Variedade } & \multirow{2}{*}{$\begin{array}{c}\text { Produção } \\
\mathrm{Kg} / \mathrm{ha}\end{array}$} & \multirow{2}{*}{$\begin{array}{l}\text { Tempo } \\
\text { (dias) de } \\
\text { floresci- } \\
\text { mento a } \\
\text { partir do } \\
\text { 1. } \text { plantio }^{2}\end{array}$} & \multirow{2}{*}{$\begin{array}{c}\text { Tempo } \\
\text { (dias) de } \\
\text { maturidade } \\
\text { a partir do } \\
\text { plantio }\end{array}$} & \multirow{2}{*}{$\begin{array}{c}\text { Altura } \\
\text { (cm) da } \\
\text { planta }\end{array}$} & \multirow{2}{*}{$\begin{array}{c}\text { Acamamen- } \\
\text { to }\end{array}$} & \multirow{2}{*}{$\begin{array}{c}\text { Número de } \\
\text { plantas } \\
\text { colhidas }\end{array}$} & \multirow{2}{*}{$\begin{array}{c}\text { Número de } \\
\text { vagens por } \\
\text { planta }\end{array}$} & \multirow{2}{*}{$\begin{array}{c}\text { Peso (g.) } \\
\text { de } 100 \\
\text { sementes }\end{array}$} & \multirow{2}{*}{$\begin{array}{c}\text { Qualidade } \\
\text { das semen- } \\
\text { tes } * *\end{array}$} & \multicolumn{2}{|c|}{ Indice de doenças +} \\
\hline & & & & & & & & & & $\begin{array}{l}\text { Vírus do } \\
\text { mosáico } \\
\text { da soja }\end{array}$ & $\begin{array}{l}\text { Mancha } \\
\text { comum } \\
\text { púrpura }\end{array}$ \\
\hline Hampton $266 \mathrm{~A}$ & 563 & 24.3 & 79.8 & 20.9 & 1.0 & 107.8 & 16.7 & 16.70 & 2.50 & 1.75 & 1.00 \\
\hline Calland & 544 & 24.0 & 82.5 & 27.8 & 1.0 & 132.0 & 12.4 & 20.25 & 2.00 & 2.00 & 1.25 \\
\hline Bossier & 539 & 24.0 & 81.3 & 20.1 & 1.0 & 112.0 & 15.6 & 15.75 & 1.75 & 2.25 & 1.00 \\
\hline Williams & 539 & 24.5 & 76.8 & 24.0 & 1.0 & 93.5 & 17.0 & 18.83 & 1.25 & 1.50 & 1.00 \\
\hline Davis & 507 & 29.8 & 80.8 & 20.1 & 1.0 & 144.3 & 13.9 & 15.13 & 1.50 & 1.50 & 1.00 \\
\hline Forrest & 498 & 24.3 & 77.5 & 23.8 & 1.0 & 141.3 & 12.3 & 15.25 & 2.75 & 1.75 & 1.00 \\
\hline Columbus & 493 & 24.5 & 78.8 & 21.6 & 1.0 & 129.5 & 13.2 & 16.88 & 2.00 & 1.75 & 1.00 \\
\hline Woodworth & 547 & 25.0 & 73.5 & 27.8 & 1.0 & 42.5 & 23.0 & 15.83 & 1.75 & 2.00 & 1.00 \\
\hline Semmes & 438 & 26.0 & 77.5 & 17.4 & 1.0 & 132.3 & 12.6 & 15.75 & 1.50 & 2.00 & 1.00 \\
\hline Tracy & 400 & 24.3 & 71.0 & 16.6 & 1.0 & 141.8 & 10.6 & 15.63 & 2.50 & 1.75 & 1.00 \\
\hline Júpiter & 400 & 32.0 & 84.3 & 50.3 & 1.0 & 117,0 & 19.7 & 13.13 & 2.00 & 1.50 & 1.00 \\
\hline Hardee & 373 & 29.8 & 80.0 & 20.1 & 1.0 & 98.0 & 24.3 & 13.63 & 1.00 & 1.75 & 1.00 \\
\hline Clark 63 & 361 & 24.8 & 79.0 & 29.0 & 1.0 & 23.5 & 27.9 & 16.63 & 2.00 & 1.50 & 1.00 \\
\hline Cobb & 359 & 26.3 & 81.8 & 17.6 & 1.0 & 27.5 & 24.5 & 16.25 & 1.50 & 1.50 & 1.00 \\
\hline Pickett 71 & 309 & 24.3 & 77.5 & 17.5 & 1.0 & 137.8 & 9.8 & 14.90 & 1.75 & 1.75 & 1.00 \\
\hline C.V. & $31.85 \%$ & $6.07 \%$ & $5.14 \%$ & $16.77 \%$ & $0.00 \%$ & $26.74 \%$ & $31.05 \%$ & $7.80 \%$ & $32.70 \%$ & & \\
\hline $\begin{array}{l}\text { Média de } \\
\text { variedade }\end{array}$ & & & & & & & & & & & \\
\hline $5 \%$ de LSD - & N.S. & 2.2 & 5.8 & 5.7 & 0.0 & 40.2 & 7.5 & 1.78 & 0.86 & & \\
\hline
\end{tabular}


TABELA 2 - Resultados đa análise đe variância para cađa variável

\begin{tabular}{|c|c|c|c|c|c|c|c|}
\hline Nome da variável & SS Total & $\begin{array}{c}\text { SS } \\
\text { Replicada }\end{array}$ & $\begin{array}{c}\text { Variedade } \\
\text { MS }\end{array}$ & $\begin{array}{l}\text { Erro } \\
\text { MS }\end{array}$ & Valor F & CV & LSD \\
\hline Graus de liberdade & 59 & 3 & 14 & 42 & & & \\
\hline Prođução kg/ha & 1330668.302 & 92089.830 & 26250.984 & 20739.636 & 1.27 & 31.85 & N.S. \\
\hline $\begin{array}{l}\text { Tempo (dias) de } \\
\text { florescimento }\end{array}$ & 474.333 & 6.733 & 26.024 & 2.459 & $10.58+$ & 6.07 & 2.2 \\
\hline $\begin{array}{l}\text { Tempo (dias) de } \\
\text { maturidade }\end{array}$ & 1344.183 & 6.183 & 46.524 & 16.383 & $2.83+$ & 5.14 & 5.8 \\
\hline Altura da planta & 4633.493 & 24.760 & 282.064 & 15.710 & $17.95+$ & 16.77 & 5.7 \\
\hline $\begin{array}{l}\text { Número de plantas } \\
\text { colhidas }\end{array}$ & 133281.933 & 2808.200 & 6938.317 & 793.745 & $8.74+$ & 26.74 & 40.2 \\
\hline $\begin{array}{l}\text { Número de vagens } \\
\text { por planta }\end{array}$ & 3176.430 & 213.086 & 129.220 & 27.482 & $4.70+$ & 31.05 & 7.5 \\
\hline Peso de 100 sementes & 249.513 & 5.985 & 12.707 & 1.562 & $8.13+$ & 7.80 & 1.78 \\
\hline Qualidade das sementes & 29.650 & 1.383 & 0.921 & 0.366 & $2.52+$ & 32.70 & 0.86 \\
\hline
\end{tabular}

NS $=$ Teste $F$ preliminar nốo significativo.

0 sinal $(t)$ após o valor $F$ indica a significância com Prob. $=.05$.

A produção de sementes variou de 309 a $363 \mathrm{~kg}$ por hectare. Essas diferenças não foram estatisticamente significativas. Júpiter, a variedade que mais produziu num experimento realizado na várzea durante a época de cultivo em 1975-76 (4.588 kg/ha), produziu apenas $400 \mathrm{~kg}$ por hectare na terra firme. A maioria das variedades incluídas neste experimento haviam sido testadas em Caldeirão, onde produziram uma quantidade incomparavelmente maior de sementes (Rahman, 1977). Muitas dessas variedades produziram colheitas extraordinárias em diversas localidades tropicais do mundo, conforme indicam experimentos realizados pelo INTSOY (Whigham, 1976). Além do mais, sementes da variedade Júpiter plantadas em 19/05/76 produziram cerca de 2.100 $\mathrm{kg}$ por hectare num canteiro de multipiicação de sementes, na Fazenda Araçá, no qual o estoque de sementes de Caldeirão estava sendo aumentado.

As principais razões da baixa produtividade das variedades neste experimento foram: 1. Plantio tardio das sementes na época de cultiv̄o da terra firme, expondo as variedades a uma falta intensa de água, em estágios críticos de crescimento da planta, durante a es- tação seca; 2. Mais de 2 meses e meio de intervalo entre a aplicaçắo de calcário e o plantio. Devido à pobreza da troca de cátions e da capacidade de retençẳo de nutrientes dos solos de terra firme em geral, a substância deve ter sido lixiviada por ocasião do plantio. Provavelmente o pH ficou incorreto; 3 . A floresta da Fazenda Araçá foi derrubada há cerca de 8 anos e durante esse tempo o solo deve ter-se empobrecido por inadequação das práticas de manejo empregadas; 4. Possível correlação entre atraso no plantio e condições fotoperiódicas desfavoráveis. Não há dados disponíveis sobre a duração relativa dos dias e noites.

As variedades levaram de 24 a 32 dias e de 71 a 84,3 dias para florescer e maturar, respectivamente (contagem feita a partir da data de germinaçăo). A altura das plantas foi muito menor neste experimento do que no Caldeirão (Rahman, 1977). A altura média de todas as variedades em Caldeirão foi de $56,1 \mathrm{~cm}$, enquanto que na Fazenda Araçá foi de somente $23,6 \mathrm{~cm}$. Não houve acamamento das plantas. O número de vagens por planta variou de 9,8 , no caso de Pickett 71 , a 27,9 , no caso de Clarck 63. Não houve diferenças significativas 
entre as variedades quanto ao peso de $100 \mathrm{se}$ mentes, que variou de 13,13 gramas para Júpiter a 20,5 gramas para Calland. Em Caldeirão o peso de 100 sementes da variedade Júpiter foi de 22,5 gramas, o segundo maior registrado. A qualidade das sementes foi afetada moderadamente neste experimento, principalmente por causa da ausência de chuvas e do calor predominante na época de maturidade. Subseqüentemente, 0 potencial germinativo das sementes ficou reduzido. A incidência de doenças foi baixa. Ocorreram somente os três tipos que haviam sido previamente observados em vutros experimentos: Virus do Mosáico Comum da Soja (SMV), Pústula Bacteriana e Mancha Púrpura. A incidência de SMV foi um pouco maior do que a observada em Caldeirão, enquanto que a Mancha Púrpura, principal problema de doença na maioria das variedades em Caldeirão, ocorreu levemente em apenas uma das variedades, Calland, na Fazenda Araçá. A Mancha Púrpura prospera em clima úmido e chuvoso; condições climáticas secas e ensolaradas não favorecem seu desenvolvimento, o que explica a diferença na incidência dessa doença entre as duas localidades. A ocorrência de Pústula Bacteriana foi também menor na Fazenda Araçá.

\section{ALGUMAS RECOMENDAÇÕES}

Com base na pequena experiência que temos na Amazônia, nos permitimos dar as seguintes recomendações:

1. Realização do plantio logo no início da época de cultivo (março) em terra firme, para que o tempo de maturação coincida com o início da estação seca. Organização das datas de plantio dos experimentos com esse objetivo. Também é recomendável correlacionar as condições fotoperiódicas com o tempo de plantio e o desempenho das variedades;
2. Planejar um grande intervalo entre as épocas de aplicação de calcário no solo e de plantio na terra firme. É necessário realizar experimentos específicos nesse sentido;

3. Realizar experimentos em vários locais de terra firme onde a floresta tenha sido derrubada há muitos anos, mas onde tenham sido seguidas diferentes práticas de manejo do solo. Isto proporcionaria informações ecológicas valiosas quanto à viabilidade do solo em relação às práticas de manejo $\mathrm{e}$ ao número de anos após a derrubada da floresta.

\section{SUMMARY}

Thirteen varieties of soy bean, which were used in a varzea experiment along with two newly introduced varieties, "Pickett 71 " and "Calland", were planted on $30 / 06 / 76$ on a terra firme farm (Fazenda Araça, $\mathrm{Km} 4$ of the Manaus-Porto Velho Highway BR-319). The forest had been cut 8 years prior. Seed production was low due to late planting. It was briefly discus the possible causes of low productivity and recommendations make for better evaluation of terra firme soy bean plantations. "Hampton 266" was the best yielding variety in this experiment with $563 \mathrm{Kgs}$ per hectare, while "Jupiter" (which produced $4,588 \mathrm{Kgs}$ per hectare in the varzea) only yielded $400 \mathrm{Kgs}$.

Soy bean planting in terra firme has to be adjusted with a harvest time in the dry season.

\section{BIBLIOGRAFIA CITADA}

RAHMAN, F.

1977 - Introdução e melhoramento de soja na várzea do rio Solimões (Caldeirão, Cacau Pireira), no período de 1975 a 1976. Acta Amazonica, $7(4): 449-454$.

WHIGHAM, D.K.

1976 - International Soybean Variety Experiment. Šecond report of results. International Agricultural publications INTSOY series, n. 11.

(Aceito para publicação em 11/03/78) 